\title{
OPTIMALISASI TEMPAT TIDUR MENGGUNAKAN MODEL SISTEM DINAMIK DI RUMAH SAKIT ZAINAL ABIDIN KOTA BANDA ACEH
}

\author{
Zurnila Marli Kesuma ${ }^{1{ }^{*}}$, Edy Fradinata $^{2)}$, Aida Fitri ${ }^{3)}$ \\ 1)*Jurusan Statistika, Universitas Syiah Kuala \\ Email: zurnila@unsyiah.ac.id \\ ${ }^{2)}$ Program Studi Teknik Industri, Universitas Syiah Kuala \\ Email: edy.fradinata@unsyiah.ac.id \\ ${ }^{3)}$ Jurusan Statistika, Universitas Syiah Kuala \\ Email: fitriaidav3@gmail.com
}

\begin{abstract}
Dynamic systems can be used for complex systems. Dynamic systems models provide a way to understand how the causes of a system's behavior, detect changes over time and determine the factors that predict significant behavior. The dynamic system model also allows the determination of scenarios that make sense as input to the decisions and policies of a system. Inpatient services at the Regional General Hospital dr. Zainoel Abidin (RSUDZA) has 710 beds distributed to several rooms. In practice, patients prefer to be treated in private hospitals rather than RSUDZA, due to the long waiting time until they get a bed for hospitalization. The purpose of this study was to optimize the use of inpatient beds at RSUDZA using dynamic systems methods. Based on the behavior of a system, we predict the number of patients with beds and create several scenarios as alternative policies for the hospital. The data used are monthly data on the number of patients with beds totaling 16 months from January 2018 to April 2019 which were obtained from RSUDZA Banda Aceh. The data were processed and analyzed using Vensim PLE version 6.3 software. The results showed that there were two rooms with not optimal bed capacity, namely the Aqsa and Raudhah rooms. The results of forecasting the number of patients with inpatient beds in the room showed that the number of patients with beds tended to decrease over time. In the scenario of optimizing the bed in the Aqsa room, it is found that scenario 3 is the best scenario by reducing the rate of patients registering for hospitalization by $10 \%$, with the MAPE value obtained by 4.3\%. Furthermore, the scenario of optimizing the bed in Raudhah's room, it was found that scenario 5 was the best scenario by reducing the rate of patients registering for inpatient treatment by $15 \%$, with the MAPE value obtained at $6.34 \%$.
\end{abstract}

Keywords: System, Dynamics, Bed, Capacity, Patient, Zainal Abidin Hospital

\begin{abstract}
ABSTRAK
Sistem dinamik dapat digunakan untuk sistem yang kompleks. Model sistem dinamik menyediakan cara untuk memahami bagaimana penyebab perilaku suatu sistem, mendeteksi perubahan dari waktu ke waktu dan penentuan faktor-faktor yang meramalkan perilaku
\end{abstract}


secara signifikan. Model sistem dinamik juga memungkinkan dalam penentuan skenario yang masuk akal sebagai masukan untuk keputusan dan kebijakan suatu sistem. Pelayanan rawat inap di Rumah Sakit Umum Daerah dr. Zainoel Abidin (RSUDZA) memiliki 710 tempat tidur yang didistribusikan ke beberapa ruangan. Dalam prakteknya, pasien lebih memilih dirawat di rumah sakit swasta daripada RSUDZA, dikarenakan lamanya menunggu sampai mendapat tempat tidur untuk rawat inap. Tujuan penelitian ini adalah untuk mengoptimalisasi pemakaian tempat tidur rawat inap di RSUDZA dengan menggunakan metode sistem dinamik. Berdasarkan perilaku suatu sistem, diramalkan jumlah pasien dengan tempat tidur dan membuat beberapa skenario sebagai alternatif kebijakan untuk rumah sakit.. Data yang digunakan yaitu data bulanan jumlah pasien dengan tempat tidur yang berjumlah 16 bulan dari bulan Januari tahun 2018 sampai bulan April tahun 2019 yang diperoleh dari RSUDZA Banda Aceh. Data diolah dan dianalisis menggunakan software Vensim PLE versi 6.3. Hasil penelitian menunjukkan bahwa terdapat dua ruangan dengan jumlah kapasitas tempat tidur belum optimal, yaitu ruang Aqsha dan Raudhah. Hasil peramalan jumlah pasien dengan tempat tidur rawat inap ruang Aqsha dan Raudhah, diperoleh bahwa jumlah pasien dengan tempat tidur cenderung menurun dari waktu ke waktu. Pada skenario pengoptimalan tempat tidur di ruangan Aqsha, diperoleh bahwa skenario 3 merupakan skenario terbaik dengan menurunkan laju pasien yang mendaftar rawat inap sebesar 10\%, dengan nilai MAPE yang diperoleh sebesar 4,3\%. Selanjutnya, skenario pengoptimalan tempat tidur di ruangan Raudhah, diperoleh bahwa skenario 4 merupakan skenario terbaik dengan menurunkan laju pasien yang mendaftar rawat inap sebesar 15\%, dengan nilai MAPE yang diperoleh sebesar 6,34\%.

\section{Kata kunci: Sistem, Dinamik, Tempat Tidur, Kapasitas, Pasien, Rumah Sakit Zainal Abidin}

\section{PENDAHULUAN}

Teknik meniru sistem dunia nyata dari waktu ke waktu dengan membangun model untuk melakukan evaluasi dan meningkatkan kinerja sistem disebut pemodelan simulasi (Kelton et al., 2010). Simulasi dapat diterapkan pada sistem yang simpel maupun kompleks, yang mana dapat membantu dalam pengambilan keputusan. Terdapat dua jenis simulasi yaitu diskrit dan kontinu. Salah satu pendekatan simulasi yang akhir-akhir ini banyak dipakai adalah dengan sistem dinamik (Fradinata,et al., 2018).

Rumah Sakit Umum Daerah dr. Zainoel Abidin (RSUDZA) Banda Aceh merupakan rumah sakit pemerintah kelas I provinsi Aceh. RSUDZA memiliki sejumlah unit pelayanan yang terdiri dari rawat jalan, rawat inap, gawat darurat, rawat intensif, 
radiologi, laboratorium, rehabilitasi medis, dan lain sebagainya. (Dinas Kesehatan Aceh 2015). Banyak pasien yang datang dari berbagai penjuru di daerah Aceh bahkan ada yang dari luar Aceh. Banyaknya pasien yang masuk menjadi sebuah pertanyaan apakah tempat tidur rawat inap di RSUDZA telah terpenuhi?

Pelayanan rawat inap di RSUDZA memiliki 710 tempat tidur yang terdiri dari beberapa kelas yaitu kelas utama, kelas I, kelas II, kelas II, isolasi dan HCU yang dibagi menjadi beberapa ruangan. Berdasarkan pengamatan di RSUDZA, terdapat beberapa pasien yang menunggu (pending) sampai tempat tidur kosong kembali. Menurut (Handayani, S.F. 2018), beberapa orang lebih memilih merawat dirinya di rumah sakit swasta daripada RSUDZA, dikarenakan lamanya menunggu sampai mendapat tempat tidur untuk rawat inap. Kasus tersebut mejadi fokus utama pada penelitian ini.

Untuk menangani kasus tersebut, dibutuhkan solusi terbaik dari berbagai kemungkinan yang terjadi. Pendekatan sistem dinamik menjadi sebuah alternatif untuk mencari solusi potensial dalam menangani masalah pengoptimalan tempat tidur, meramalkan situasi kedepan dan memberikan skenario atau kebijakan yang dapat dijadikan sebagai acuan untuk masalah pengoptimalan tempat tidur di RSUDZA.

Simulasi adalah operasi dari model suatu sistem yang mengacu pada kumpulan metode dan aplikasi untuk meniru perilaku dari sistem yang sebenarnya tanpa perlu membuat sistem asli yang dapat menghabiskan banyak sumber daya dan biaya, tetapi dengan mempelajari perilaku model yang memiliki beberapa kesamaan dengan sistem sebenarnya (Sapiri, Zulkepli Hew, Ahmad, Zainal Abidin, \& Hawari, 2017).

Sistem dinamik digambarkan sebagai teori tentang bagaimana suatu sistem berfungsi, memberikan penjelasan dan memprediksi perilaku sistem. Perilaku suatu sistem didefinisikan sebagai tren atau variasi yang dihasilkan oleh sistem yang disimulasikan dalam bentuk grafik atau tabel numerik. Pendiri sistem dinamik yaitu Jay Forrester pada tahun 1950-an mengkarakteristikkan sistem dinamik sebagai metodologi dalam penyelidikan, analisis, dan pemodelan suatu perilaku sistem yang kompleks secara menyeluruh, di mana loop umpan balik sangat penting dalam memahami hubungan timbal balik antara variabel-variabel (Moran, 2007). Pemodelan sistem dinamik memiliki tahapan yang diawali dan diakhiri dengan pemahaman sistem dan permasalahannya sehingga membentuk suatu lingkaran tertutup (Fradinata, Suthummanon, \& Suntiamorntut, 2018). Tahapan dalam proses pemodelan sistem dinamik dapat dilihat pada Gambar 1.

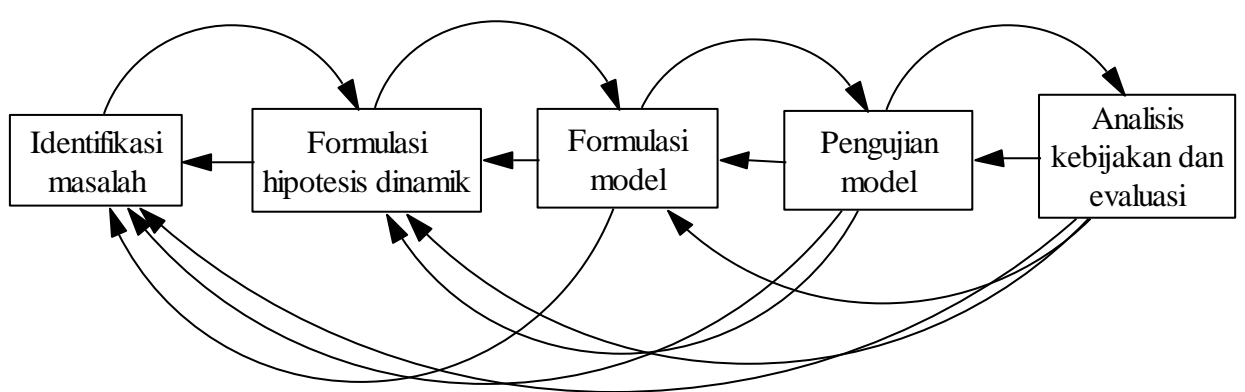

Gambar 1. Tahapan dalam proses pemodelan sistem dinamik (Sterman, 2000)

- Identifikasi Masalah

Model yang bermanfaat dibutuhkan untuk mengatasi masalah khusus. Hal ini lebih 
penting dilakukan, daripada memodelkan seluruh sistem. Masalah yang dipilih harus dinamis dan memiliki sifat umpan balik.

- Formulasi Hipotesis Dinamik

Formulasi hipotesis dinamik membantu menggambarkan pemetaan permasalahan dan membangun model. Sejumlah alat bantu dapat digunakan untuk memetakan dan membangun model, seperti diagram sektor, rich picture diagram, causal loop diagram (CLD) dan stock flow diagram (SFD).

- Formulasi Model

Formulasi model menjelaskan hubungan perilaku model, kondisi. CLD yang telah dikembangkan, ditransformasi menjadi SFD menggunakan perangkat lunak sitem dinamik (Vensim, Stella dan iThink) dengan persamaan model untuk menjalankan model tersebut. Secara matematis, stok dan aliran dapat disajikan dalam bentuk persamaan integral dan dengan persamaan yang sama, tingkat perubahan stok adalah aliran masuk dikurang aliran keluar, yang didefinisikan dengan persamaan differensial (Fradinata, Suthummanon, \& Suntiamorntut, 2015):

$$
t=\int_{t_{o}}^{t}(i-o) d s+s\left(t_{o}\right) \quad \frac{d(s t o k)}{d t}=i-o
$$

Keterangan:

$\mathrm{t}=$ Periode $; \mathrm{i}=$ Arus aliran masuk $; \mathrm{o}=$ Arus aliran keluar; $\mathrm{s}=$ Stok

- Pengujian Model

Model yang telah dikembangkan, kemudian dilakukan pengujian melakukan uji verifikasi dengan melakukan checking pada program program vensim, ketika vensim tidak menampilkan pesan error, maka model tersebut dikatan verified (bebas error) dan model sudah bisa dijalankan atau running. Dan uji validasi dengan menggunakan Mean Absolute Percentage Error (MAPE).

$$
\text { MAPE }=\frac{1}{\mathrm{n}} \sum_{t=1}^{n} \frac{\left|y_{t}-\hat{y}_{t}\right|}{\hat{y}_{t}} \times 100 \%
$$

Keterangan:

$\hat{y}_{t}=$ data hasil simulasi; ${ }^{y_{t}}=$ data aktual; $n=$ jumlah periode/banyaknya data; $t=$

Periode

Rumah Sakit Umum Daerah dr. Zainoel Abidin (RSUDZA) adalah salah satu instansi pelayanan publik yang bertugas memberikan pelayanan medis langsung kepada masyarakat khususnya pelayanan rawat jalan, pelayanan rawat inap maupun pelayanan gawat darurat. Selain memberikan pelayanan medis, RSUDZA Banda Aceh juga menjadi tempat pendidikan bagi calon dokter, calon dokter spesialis, calon perawat dan calon tenaga kesehatan lainnya. Saat ini, RSUDZA adalah rumah sakit negeri kelas A dengan meraih akreditasi paripurna dari Komite Akreditasi Rumah Sakit (KARS) pada 2015 yang telah ditetapkan sebagai rujukan tertinggi atau menjadi rumah sakit pusat rujukan di Aceh.

RSUDZA memiliki sejumlah unit pelayanan yaitu unit yang menyelenggarakan upaya kesehatan yang terdiri dari rawat jalan, rawat inap, gawat darurat, rawat intensif, radiologi, laboratorium, rehabilitasi medis, dan lain sebagainya. Saat ini kapasitas rawat inap di RSUDZA adalah 710 tempat tidur.

Berdasarkan standar pengukuran jasa pelayanan kesehatan nasional, indikator- 
indikator pelayanan rumah sakit yang dapat dipakai untuk mengetahui tingkat pemanfaatan, mutu, dan efisiensi pelayanan rumah sakit dan merupakan indikator-indikator yang bersumber dari sensus harian rawat inap adalah BOR (Bed Occupancy Ratio) atau persentase pemakaian tempat tidur, AVLOS (Average Length of Stay) atau rata-rata lama rawat seorang pasien dan BTO (Bed Turn Over) atau angka perputaran tempat tidur (Kesuma \& Rahayu, 2017).

\section{METODOLOGI}

Data yang digunakan dalam penelitian ini berupa data sekunder yang diperoleh dari Rumah Sakit Umum Daerah dr. Zainoel Abidin (RSUDZA) Banda Aceh. Yaitu data bulanan jumlah pasien dengan tempat tidur yang berjumlah 16 bulan dengan total pasien rawat inap sebesar 67.151 pasien dari bulan Januari tahun 2018 sampai bulan April tahun 2019. Data diolah dan dianalisis menggunakan software Vensim PLE versi 6.3 dan $R$ untuk menyimulasikan serta meramalkan jumlah pasien dengan tempat tidur.

Prosedur penelitian yang dilakukan pada penelitian ini adalah sebagai berikut: (Axella, O., \& Suryani, E. 2012.)

1) Identifikasi masalah dan variabel yang berpengaruh terhadap optimalisasi tempat tidur. Pada tahap ini dicari secara selektif variabel yang dibutuhkan dalam penelitian dengan membaginya menjadi kategori endogen dan eksogen. penentuan variabel endogen dan eksogen mengacu pada variabel yang mempengaruhi dan dipengaruhi oleh variabel lain untuk endogen, dan variabel yang mempengaruhi variabel lain untuk eksogen.

2) Melakukan analisis deskriptif yaitu summary data dan membuat plot data.

3) Membuat formulasi hipotesis dinamik atau konseptual model dengan menggunakan alat bantu diagram lingkaran sebab akibat atau Causal Loop Diagram (CLD). Pembuatan konsep CLD dilakukan dengan mengidentifikasi serta menghubungkan antar masing-masing variabel yang memiliki hubungan sebab akibat atau yang berpengaruh terhadap optimalisasi tempat tidur berdasarkan alur pelayanan pasien masuk di RSUDZA (Gambar 2) dengan menggunakan bantuan tool pada software Vensim PLE versi 6.3. berdasarkan konsep (Dengerfield, B. 2014).

4) CLD yang telah dikembangkan kemudian ditransformasi menjadi stock flow diagram (SFD) untuk selanjutnya dibuat formulasi matematis dengan menghubungkan variabel-variabel yang telah diidentifikasi dalam model konseptual dengan bahasa simbolik.

5) Simulasi model berdasarkan model SFD yang telah dibuat dengan menggunakaan persamaan differensial (persamaan 1)

6) Verifikasi dan validasi

Pada tahap verifikasi, dilakukan checking pada program Vensim. Proses verifikasi dilakukan ketika Vensim tidak menampilkan pesan error, maka model tersebut dikatan verified (bebas error) dan model sudah bisa dijalankan atau running. Selanjutnya dilakukan pengujian validasi model yang bertujuan untuk mengetahui tingkat keakuratan model dalam merepresentasikan sistem yang sebenarnya. Uji MAPE (Mean Absolute Percentage Error) digunakan untuk memvalidasi model dengan menggunakan persamaan (2) hingga diperoleh nilai MAPE kurang dari $20 \%$.

7) Analisis Kebijakan dan Evaluasi

Pada tahap ini, dilakukan perubahan nilai-nilai laju untuk mencari solusi atau 
menemukan evaluasi kebijakan yang dapat disarankan agar model meningkat menjadi lebih baik. Dua hal penting dalam evaluasi kebijakan adalah skenario kasus terbaik dan terburuk. Dalam pendekatan skenario terbaik dan terburuk, perubahan dilakukan dengan mempertimbangkan perubahan nilai laju skenario terburuk maupun terbaik.

\section{HASIL DAN PEMBAHASAN}

\subsection{Analisis Deskriptif}

Semakin lama pasien dirawat, maka jumlah pasien dengan tempat tidur atau yang menggunakan tempat tidur akan semakin banyak. Berikut gambaran kondisi terkini tentang perbandingan kapasitas tempat tidur terhadap jumlah pasien dengan tempat tidur.

Tabel 1. Summary jumlah pasien dengan tempat tidur

\begin{tabular}{|c|c|}
\hline Nilai & $\begin{array}{c}\text { Jumlah pasien dengan tempat } \\
\text { tidur }\end{array}$ \\
\hline Rata-rata & 17.382 Pasien \\
\hline Maksimum & 19.100 Pasien \\
\hline Minimum & 14.334 Pasien \\
\hline
\end{tabular}

Rata-rata jumlah pasien dengan tempat tidur sebesar 17.382 pasien, jumlah pasien dengan tempat tidur tertinggi pada bulan Oktober 2018 sebesar 19.100 pasien dan terendah pada bulan Juni 2018 sebesar 14.334 pasien. Secara keseluruhan, kapasitas tempat tidur rawat inap telah tercukupi. Selanjutnya, dilihat secara spesifik perbandingkan jumlah pasien dengan tempat tidur per tiap ruangan terhadap kapasitas tempat tidur pada ruangan tersebut. Terdapat dua ruangan yang kapasitas tempat tidur belum tercukupi, setelah dilakukan pperbandingan data jumlah pasien dengan tempat tidur terhadap kapasitas tepat tidur yang tersedia. Dua ruangan yang belum optimal yaitu ruangan aqsha yang merupakan ruangan rawat inap khusus untuk pasien penyakit dalam dan ruangan raudhah yang berfungsi sebagai ruangan khusus pasien yang akan menjalani bedah, baik bedah mulut, bedah saraf maupun yang lainnya.

\subsection{Konseptualisasi Model}

Diagram sebab akibat optimalisasi tempat tidur dibangun berdasarkan proses alur pelayanan pasien masuk rumah sakit. Untuk memudahkan membangun pemodelan, perlu dipahami alur pelayanan pasien masuk RSUDZA. Model optimalisasi tempat tidur digambarkan pada diagram sebab akibat yang dapat dilihat pada Gambar 2. 


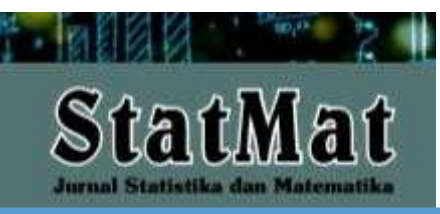

P-ISSN: 2655-3724 E-ISSN: 2720-9881

STATMAT (Jurnal Statistika dan Matematika), Vol. 3, No. 1, January 2021

Artikel ke-7, Halaman: 58-70

@Prodi S-1 Matematika FMIPA Unpam

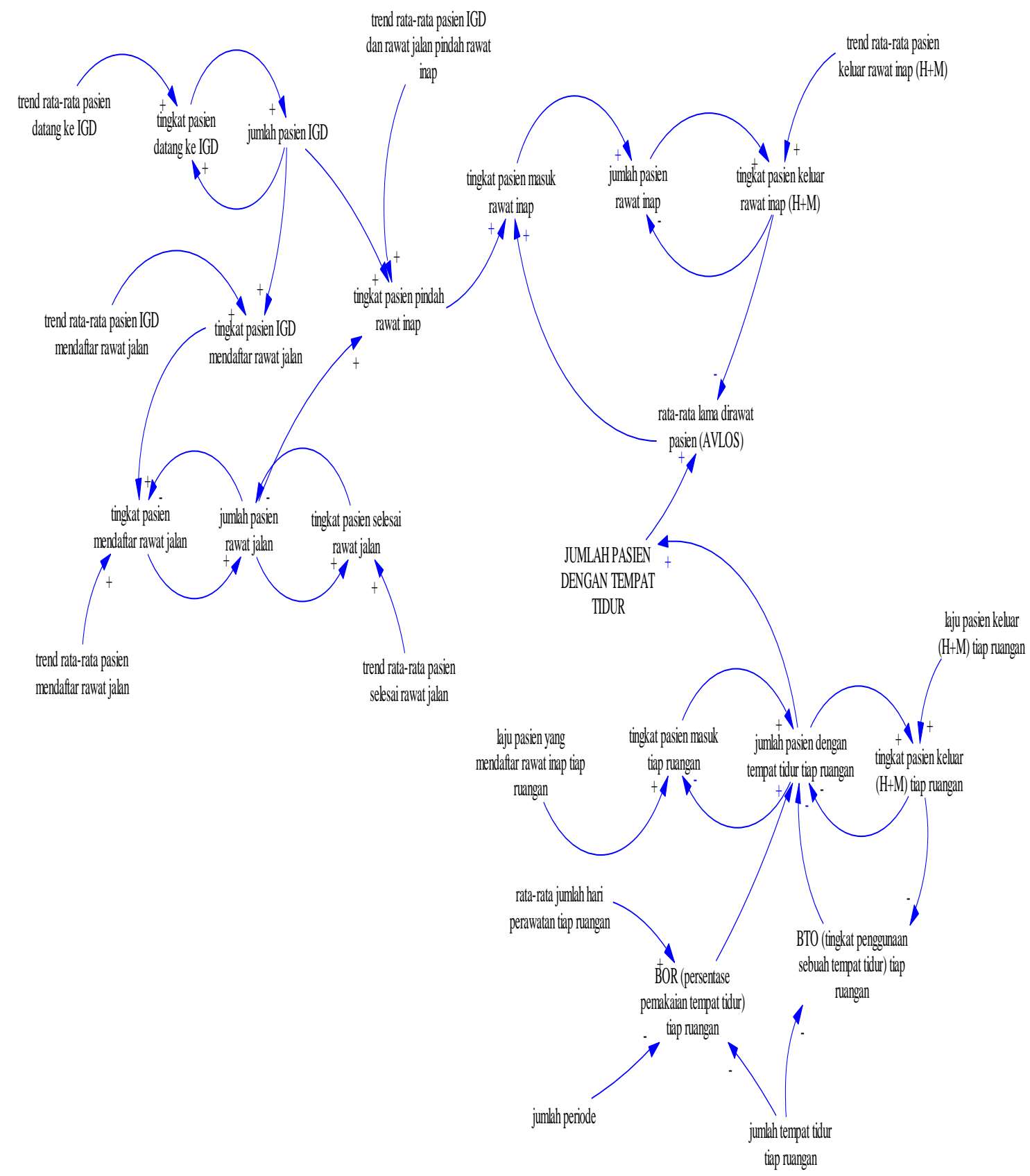

Gambar 2. Diagram sebab akibat (CLD)

\section{a. Perumusan Model}

Formulasi submodel jumlah pasien dengan tempat tidur rawat inap dan per masingmasing ruangan dalam software vensim ditunjukkan pada Gambar 3. 

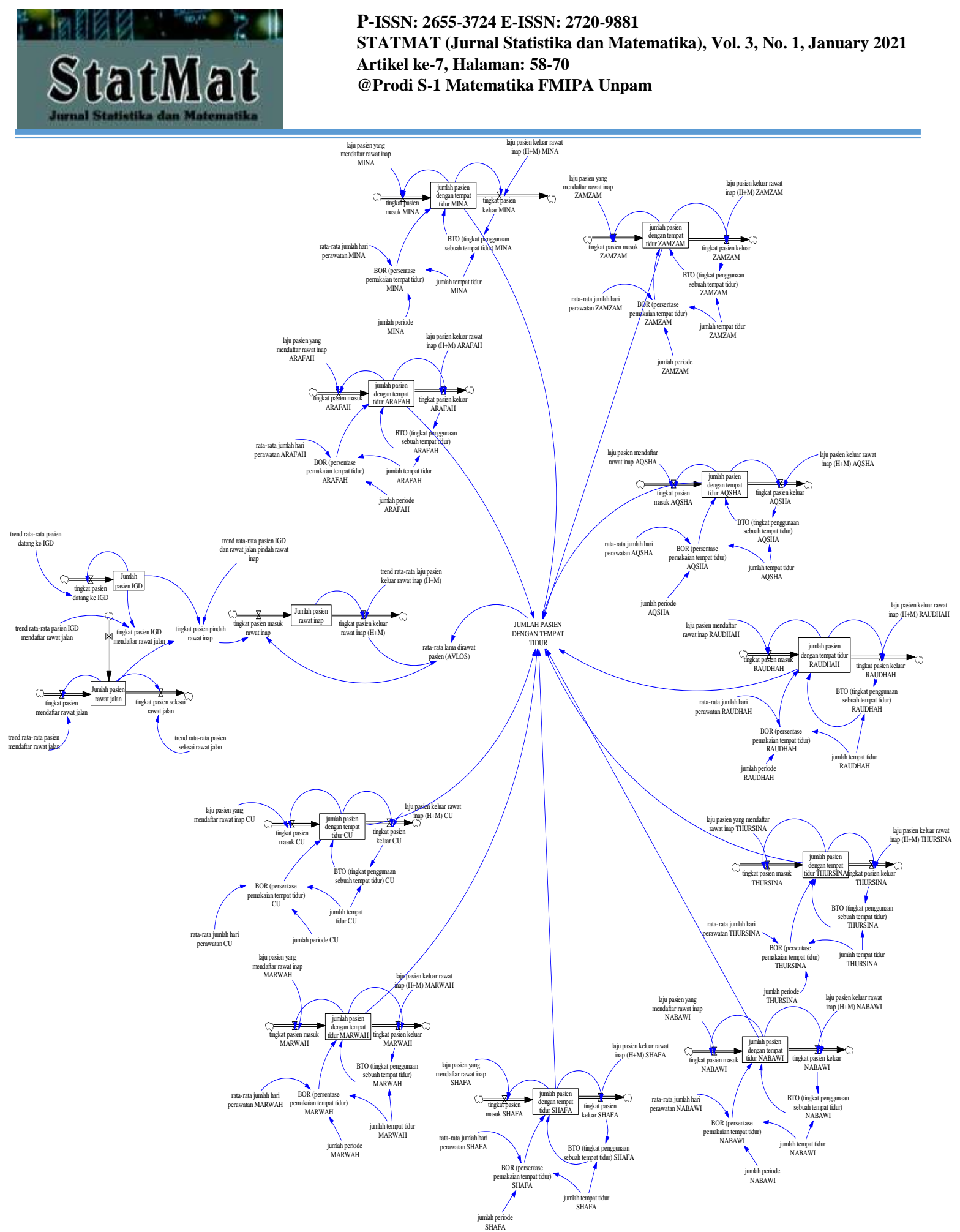

Gambar 3. Diagram stok dan aliran submodel jumlah pasien dengan tempat tidur rawat inap per masing-masing ruangan

\section{b. Hasil Simulasi Model}

Hasil simulasi model sistem dinamik dari submodel jumlah pasien dengan tempat tidur rawat inap keseluruhan serta pada ruang Aqsha dan Raudhah dapat dilihat pada Gambar 4. 


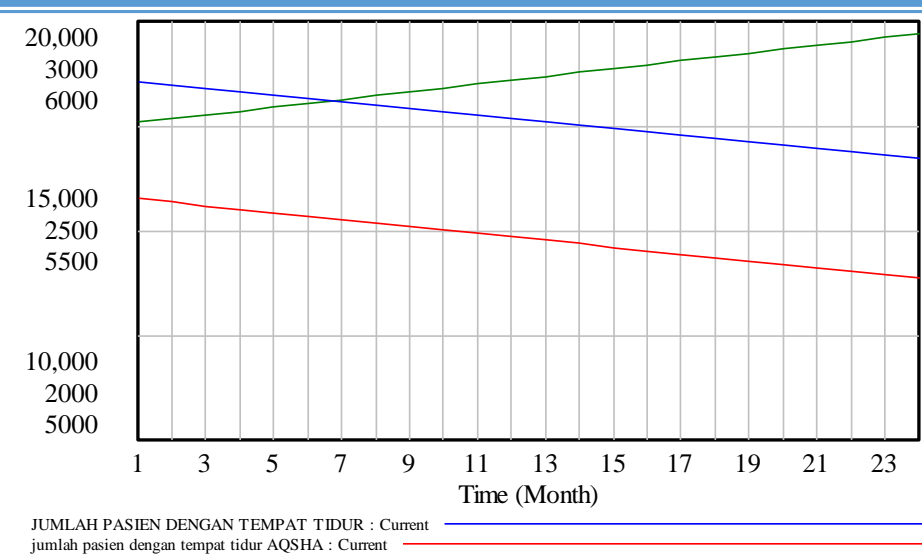

\section{Gambar 4. Grafik hasil simulasi jumlah pasien dengan tempat tidur rawat inap berdasarkan ruangan dari bulan Jan 2018 - Des 2019}

Dapat dilihat pada Gambar 4 secara keseluruhan dan berdasarkan ruang Aqsha dan Raudhah. jumlah pasien dengan tempat tidur keseluruhan dan ruang Aqsha cenderung menurun dari waktu ke waktu, sedangkan jumlah pasien dengan tempat tidur ruang Raudhah cenderung naik waktu ke waktu.

\section{Verifikasi Dan Validasi Model}

Hasil uji verifikasi semua variabel pada model simulasi dalam software Vensim menunjukkan bahwa model yang telah dikembangkan sudah terverifikasi.

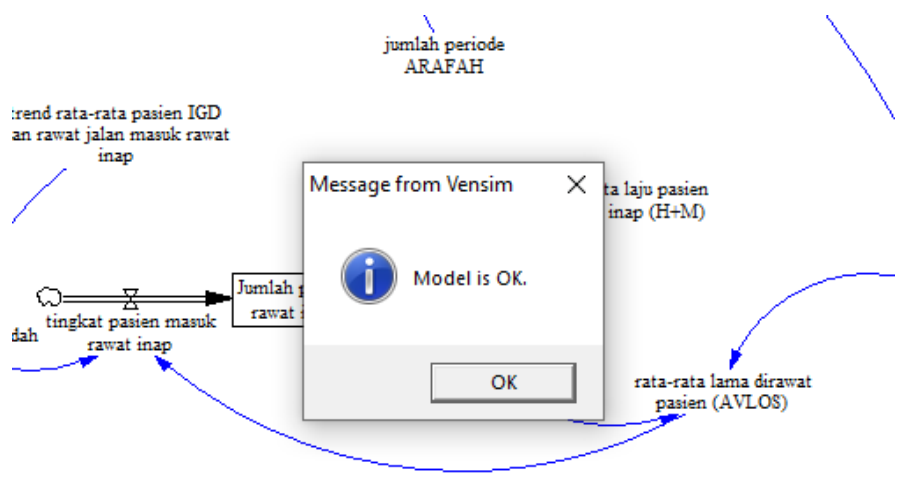

Gambar 5. Model sudah terverifikasi

Validasi model dilakukan dengan menghitung nilai Mean Absolute Percentage Error (MAPE) dari data hasil simulasi dengan menggunakan alat bantu software $R$ untuk memastikan apakah model layak atau tidak. Nilai MAPE yang diperoleh harus lebih kecil dari 20\% yang berarti model telah layak digunakan. Hasil nilai MAPE yang dihitung dapat dilihat pada Tabel 2. 
Tabel 2. Nilai MAPE

\begin{tabular}{|l|l|}
\hline \multicolumn{1}{|c|}{ Variabel } & Nilai MAPE \\
\hline Jumlah pasien IGD & $4,88 \%$ \\
\hline Jumlah Pasien Rawat Jalan & $16,94 \%$ \\
\hline Jumlah Pasien Rawat Inap & $6,6 \%$ \\
\hline jumlah pasien dengan tempat tidur rawat inap keseluruhan & $6,22 \%$ \\
\hline jumlah pasien dengan tempat tidur rawat inap ruang Arafah & $9,41 \%$ \\
\hline jumlah pasien dengan tempat tidur rawat inap ruang Mina & $11,78 \%$ \\
\hline jumlah pasien dengan tempat tidur rawat inap ruang Zamzam & $15,94 \%$ \\
\hline jumlah pasien dengan tempat tidur rawat inap ruang Aqsha & $5,98 \%$ \\
\hline jumlah pasien dengan tempat tidur rawat inap ruang Raudhah & $6,8 \%$ \\
\hline jumlah pasien dengan tempat tidur rawat inap ruang Thursina & $13,3 \%$ \\
\hline jumlah pasien dengan tempat tidur rawat inap ruang Nabawi & $14,94 \%$ \\
\hline jumlah pasien dengan tempat tidur rawat inap ruang Shafa & $12,91 \%$ \\
\hline jumlah pasien dengan tempat tidur rawat inap ruang Marwah & $12,75 \%$ \\
\hline jumlah pasien dengan tempat tidur rawat inap ruang Care Unit & $8,17 \%$ \\
\hline
\end{tabular}

Berdasarkan Tabel 2, hasil nilai MAPE yang didapat dibawah 20\%, yang berarti model yang telah dibangun telah valid atau layak digunakan.

\section{Skenario Dan Hasil Simulasi}

\section{Skenario pengoptimalan tempat tidur di ruangan Aqsha}

Ruangan rawat inap Aqsha memiliki kapasitas tempat tidur yang belum optimal. Pada skenario ini, dilakukan skenario kebijakan untuk mengoptimalkan tempat tidur di ruangan Aqsha. Sebelumnya diketahui bahwa laju pasien yang mendaftar rawat inap di ruangan Aqsha sebesar 63\%. Diharapkan kapasitas tempat tidur yang tersedia optimal, maka dilakukan beberapa skenario perubahan nilai laju pasien yang mendaftar rawat inap ruang Aqsha. Berikut beberapa skenario penurunan persentase laju pasien mendaftar rawat inap ruang Aqsha.

Tabel 3. Skenario penurunan laju pasien mendaftar rawat inap ruang Aqsha

\begin{tabular}{|l|l|l|}
\hline Skenario & $\begin{array}{l}\text { Penurunan persentase laju } \\
\text { pasien mendaftar rawat inap }\end{array}$ & Nilai MAPE \\
\hline 1 & $3 \%$ & $5.23 \%$ \\
\hline 2 & $5 \%$ & $4.82 \%$ \\
\hline 3 & $8 \%$ & $4.25 \%$ \\
\hline 4 & $10 \%$ & $4.22 \%$ \\
\hline 5 & $13 \%$ & $4.38 \%$ \\
\hline 6 & $15 \%$ & $4.61 \%$ \\
\hline
\end{tabular}

Tabel 3 menunjukkan skenario 4 adalah skenario yang terbaik, karena memiliki nilai MAPE paling kecil dari pada skenario yang lain yaitu sebesar 4,22\%. Skenario 4 merupakan penurunan persentase laju pasien mendaftar rawat inap sebesar $10 \%$, dari $63 \%$ turun menjadi $53 \%$. Berikut grafik perubahan skenario 4 (Gambar 6). 

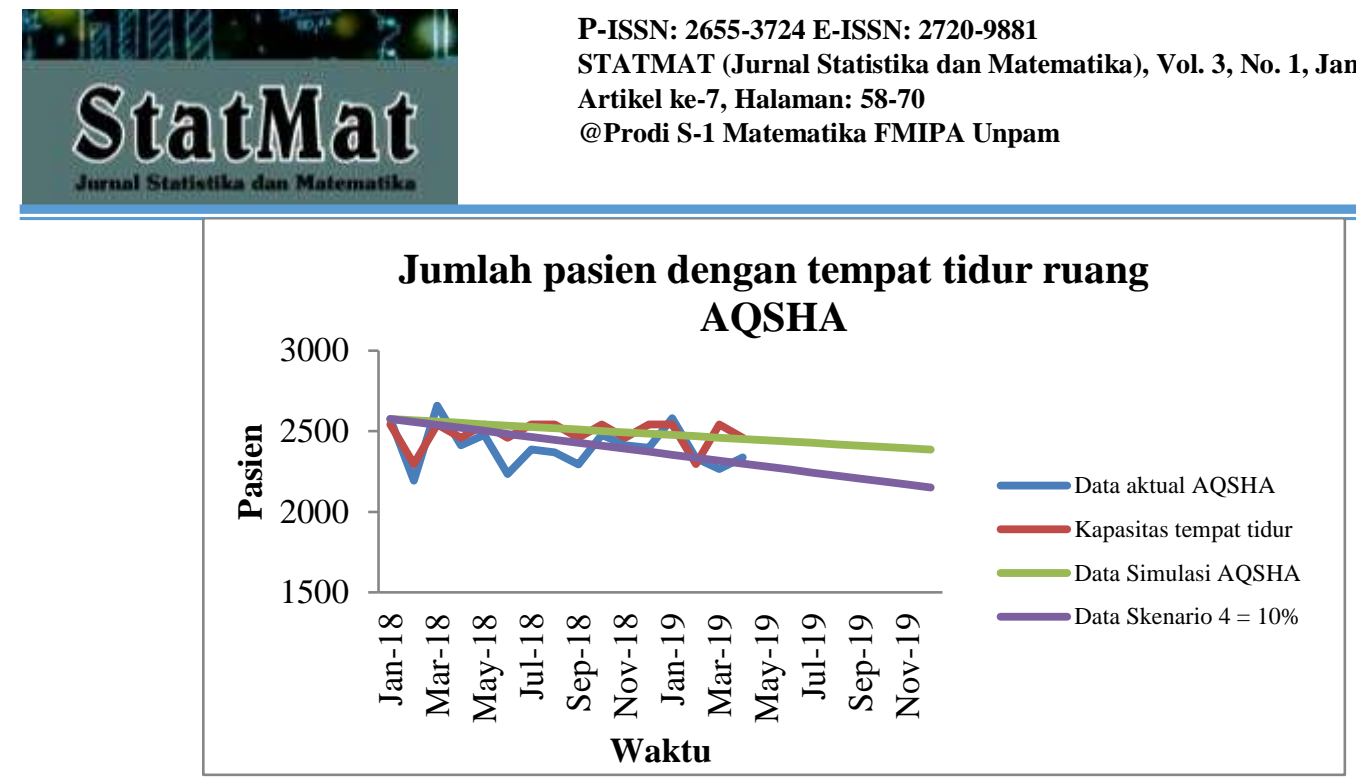

\section{Gambar 6. Grafik perbandingan jumlah pasien dengan tempat tidur Aqsha skenario 4}

Gambar 6 menunjukkan bahwa setelah dilakukan skenario 4 dengan menurunkan laju pasien yang mendaftar rawat inap sebesar $10 \%$, diperoleh bahwa kapasitas tempat tidur menjadi lebih optimal dikarenakan pasien yang terus menurun seiring waktu berjalan dan jumlah pasien dengan tempat tidur berada dibawah kapasitas tempat tidur yang tersedia.

\section{Skenario pengoptimalan tempat tidur di ruang Raudhah}

Ruangan rawat inap Raudhah memiliki kapasitas tempat tidur yang belum optimal. Maka dilakukan skenario kebijakan untuk mengoptimalan tempat tidur di ruangan Raudhah. Sebelumnya diketahui bahwa laju pasien yang mendaftar rawat inap di ruangan Raudhah sebesar $83 \%$. Diharapkan kapasitas tempat tidur yang tersedia optimal, maka dilakukan beberapa skenario perubahan nilai laju pasien yang mendaftar rawat inap ruang Raudhah. Berikut beberapa skenario penurunan persentase laju pasien mendaftar rawat inap ruang Raudhah.

Tabel 3. Skenario penurunan laju pasien mendaftar rawat inap ruang Raudhah

\begin{tabular}{|l|l|l|}
\hline skenario & $\begin{array}{l}\text { Penurunan persentase laju } \\
\text { pasien mendaftar rawat inap }\end{array}$ & Nilai MAPE \\
\hline 1 & $3 \%$ & $6.68 \%$ \\
\hline 2 & $5 \%$ & $6.62 \%$ \\
\hline 3 & $8 \%$ & $6.53 \%$ \\
\hline 4 & $10 \%$ & $6.47 \%$ \\
\hline 5 & $15 \%$ & $6.34 \%$ \\
\hline 6 & $20 \%$ & $6.51 \%$ \\
\hline
\end{tabular}

Tabel 3 menunjukkan skenario 5 adalah skenario yang terbaik, karena memiliki nilai MAPE paling kecil dari pada skenario yang lain yaitu sebesar 6,34\%. Skenario 5 merupakan penurunan persentase laju pasien mendaftar rawat inap sebesar $15 \%$, yaitu dari $83 \%$ turun menjadi 68\%. Berikut grafik perubahan skenario 5 (Gambar 7). 


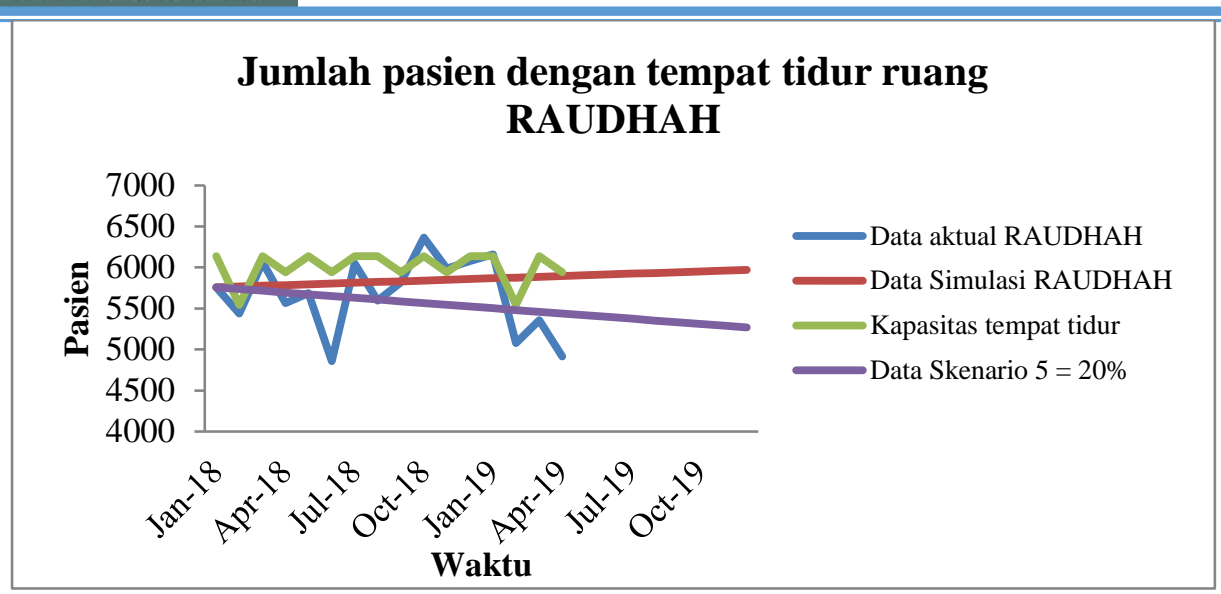

\section{Gambar 7. Grafik perbandingan jumlah pasien dengan tempat tidur Raudhah} skenario 5

Gambar 7 menunjukkan bahwa setelah dilakukan skenario 5 dengan menurunkan laju pasien yang mendaftar rawat inap sebesar $15 \%$, diperoleh bahwa kapasitas tempat tidur menjadi lebih optimal dikarenakan jumlah pasien yang terus menurun seiring waktu berjalan, berada didalam kisaran grafik data aktual dan jumlah pasien dengan tempat tidur berada dibawah kapasitas tempat tidur yang tersedia.

\section{SIMPULAN}

Berdasarkan hasil penelitian diketahui bahwa terdapat dua ruangan dengan jumlah kapasitas tempat tidur yang belum optimal, yaitu ruang Aqsha untuk pasien khusus penyakit dalam dan ruang Raudhah untuk pasien khusus yang menjalani perawatan bedah. Dari 710 tempat tidur rawat inap yang tersedia di RSUDZA, jumlah pasien dengan tempat tidur cenderung menurun, kecuali di ruang Raudhah yang cenderung meningkat dari waktu ke waktu. Untuk skenario kebijakan yang dilakukan, untuk ruang Aqsha, skenario 4 adalah yang terbaik,yaitu menurunkan nilai laju pasien yang mendaftar rawat inap ruang Aqsha sebesar $10 \%$, dengan nilai MAPE yang diperoleh sebesar 4,3\%. Sedangkan di ruang Raudhah, diperoleh bahwa skenario 5 adalah yang terbaik yaitu menurunkan nilai laju pasien yang mendaftar rawat inap sebesar $15 \%$ dengan nilai MAPE sebesar 6,34\%. 


\section{DAFTAR PUSTAKA}

Axella, O., \& Suryani, E. (2012). Aplikasi Model Sistem Dinamik Untuk Menganalisis Permintaan Dan Listrik Sektor Industri (Studi Kasus: Jawa Timur). Institut Teknologi Sepuluh Nopember, Surabaya.

Dengerfield, B. (2014). System Hingking And System Dynamics: A Primer. In S. Brailsford, L. Churilov, \& B. Dangerfield Menagement Desicion Making. Wiley \& Sons, United Kingdom: John.

Dinas Kesehatan Aceh. (2015). Profil Kesehatan Aceh, Dinas Kesehatan Aceh, Banda Aceh.

Fradinata, E., Suthummanon, S., \& Suntiamorntut, W. (2015). Forecasting determinant of cement demand in Indonesia with artificial neural network. Journal of Asian Scientific Research. 5(7): 373.

Fradinata, E., Suthummanon, S., \& Suntiamorntut, W. (2018). Initial optimal parameters of artificial neural network and support vector regression. International Journal of Electrical and Computer Engineering. 8(5): 3341.

Handayani, S.F. (2018). Sistem Pelayanan Prima Bagi Masyarakat Kurang Mampu Pada Rumah Sakit Umum Zainoel Abidin Banda Aceh.Universitas Islam Negeri Ar-Raniry, Banda Aceh.

Kelton, W., Sadowski, R., \& Sadowski, D. (2007). Simulation with Arena, McGraw-Hill. New York.

Kesuma, Z. M., \& Rahayu, L. (2017). Identifikasi status gizi pada remaja di kota Banda Aceh. STATISTIKA: Journal of Theoretical Statistics and Its Applications. 17(2): 63 69.

Moran, A. (2007). Study of the influence of goal alignment on multi-organizational projects: A system dynamics approach. Oklahoma State University.

Sapiri, H., Zulkepli Hew, J., Ahmad, N., Zainal Abidin, N., \& Hawari, N. N. (2017). Introduction to system dynamic modelling and vensim software: UUM Press.

Sterman, J. (2000). Instructor's Manual to Accompany Business Dyanmics: Systems Thinking and Modeling for a Complex World: McGraw-Hill. 